УДК: $726.54,7.033 .1,7.033 .2$

ББК: 63.4(3), 85.113(3)

A43

DOI: $10.18688 /$ aa199-2-23

H. Çetinkaya

\title{
Four Newly Discovered Churches in Bithynia
}

Region of Bithynia was named after the tribe of Bityn who were from Thrace and settled in this area in the $5^{\text {th }}$ century B.C.E. [9, VII. 75]. Among all cities of Bithynia, the two most important ones, Nicomedia and Nicaea, were founded during Hellenistic period. Both were established by the beginning of the $4^{\text {th }}$ century B.C.E.

The subject of this article is the discovery of three churches from Nicaea (Fig. 1) and one from Prusia ad Olympum (Ill. 37).

Foundation of Nicaea, according to the inscription on the Lefke gate of the city walls, was by Dionysos and Heracles [18, p. 29]. Soon after the death of Alexander the Great this area must have been controlled by Antigonos Monophtalmos, after whom the establishment was named as Antigonia. Upon his defeat in 301 B.C.E. the area was under the jurisdiction of Lysimachos and the city was renamed after his wife's namesake as Nicaea [3, pp. 354-356]. According to another opinion, there existed a city at the same location long before the Hellenistic foundations namely Helikore [13, p. 10]. Since this information is obtained from a side note of a $10^{\text {th }}-11^{\text {th }}$-century Byzantine text, it has to be approached with caution.

Upon the defeat of Pontus king Mithradates VI by Romans, local kingdoms became part of Roman republic. Last Bithynian king Nicomedes IV bequeathed his kingdom to Rome in 74 B.C.E. [1, p. 75 (I-XIII)]. Battles between Rome and Pontic kings ended in 63 B.C.E. after which a new Roman province with the name of Bithynia et Pontus was created [2, p. 28]. In the following centuries Nicaea flourished. During Roman Empire administration of Bithynia was re-organized and in the $4^{\text {th }}$ century A.C.E. it was given a special status which lasted until the $7^{\text {th }}$ century A.C.E. After this date the land of Bithynia was divided between Opsikion and Optimatoi provinces [10, pp. 178-182, 315-319].

Nicaea reached its apex in the first quarter of the $4^{\text {th }}$ century A.C.E. when it was chosen to be the site of the $1^{\text {st }}$ Ecumenical Council in 325. The number of churches and monastic establishments increased soon after official acceptance of Christianity as the State Religion at the end of the $4^{\text {th }}$ century A.C.E. Basing on the ancient and later sources dedication and foundation dates for churches were suggested. According to the most authoritative work on this subject, there were 22 churches and monasteries in and around Nicaea [11, pp. 105-126]. During recent years several more monastic settlements and churches were added to that number. Below are the churches which are the main theme of this article.

One of the newly discovered churches was located by Lefke gate. This gate was established with another gate, currently named Istanbul gate, in 78-79 A.C.E. according to the inscription on it. Whether they were connected by the city walls is not clear [16, p. 438]. There must 


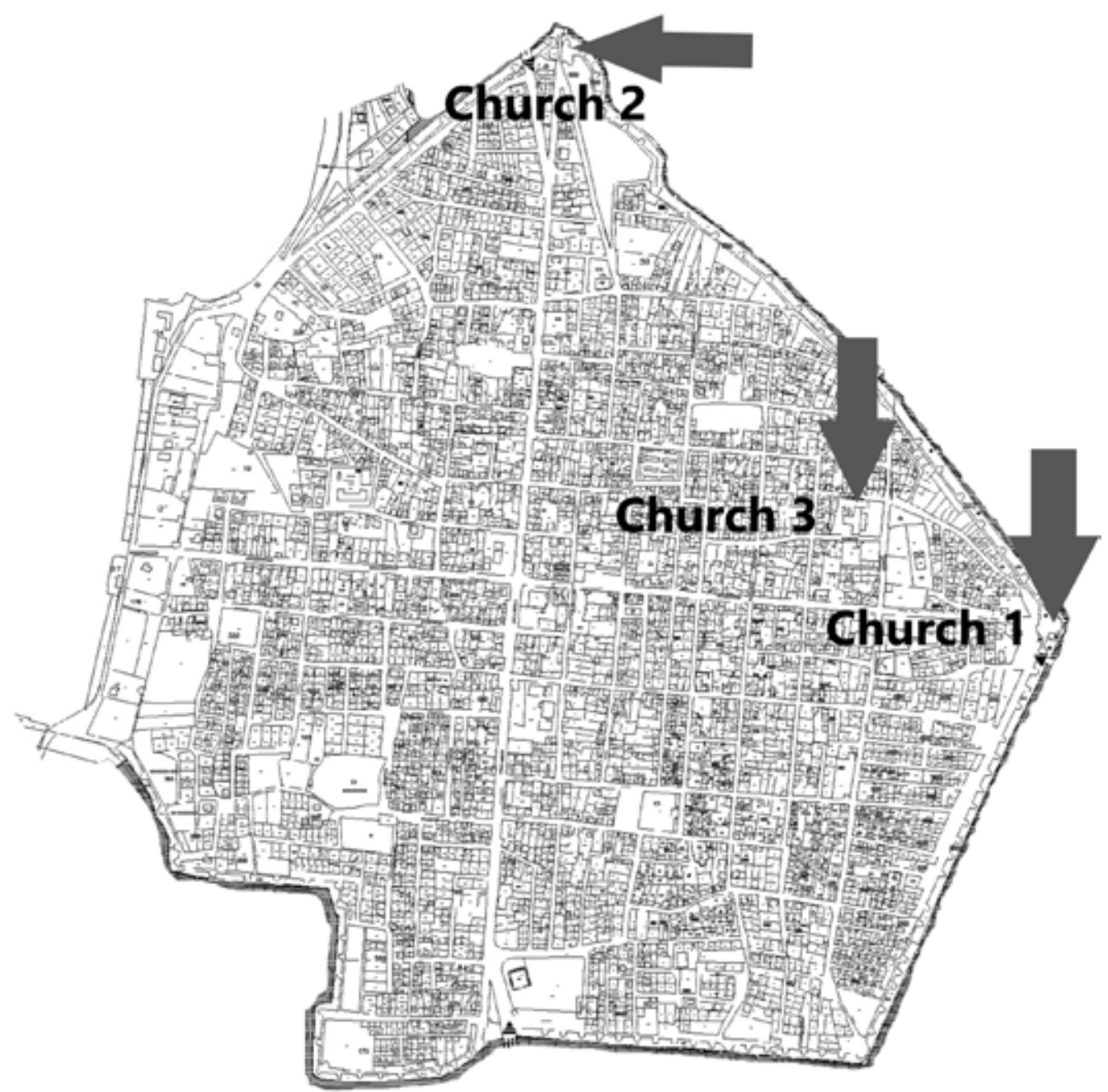

Fig. 1. Sites of newly discovered churches on the map of Nicaea (Bursa Greater City Municipal archive www.bursa. bel.tr/?sayfa=imar_plan_digisiklikleri\&id=170)

have been city walls since the foundation of the city. After the earthquakes during the reign of Hadrian, gates were already part of the city walls [18, p. 29]. Around 268-269 A.C.E. two more gates were added to the city walls hence having one major gate at each cardinal direction $[15$, p. 3]. Prior to the First Ecumenical Council in 325 A.C.E. the city walls must have gone through a restoration. Series of earthquakes and attacks of Crusaders and Seldjuks damaged the city walls which were restored immediately afterwards. The last major restoration of the city walls was during the Palaeologans [5, p. 83].

Nicaea was founded with grid plan. Original height of the paved Roman road is partially visible next to a Turkish bath of sultan Murat I, approximately 3 metres below the current road level. 


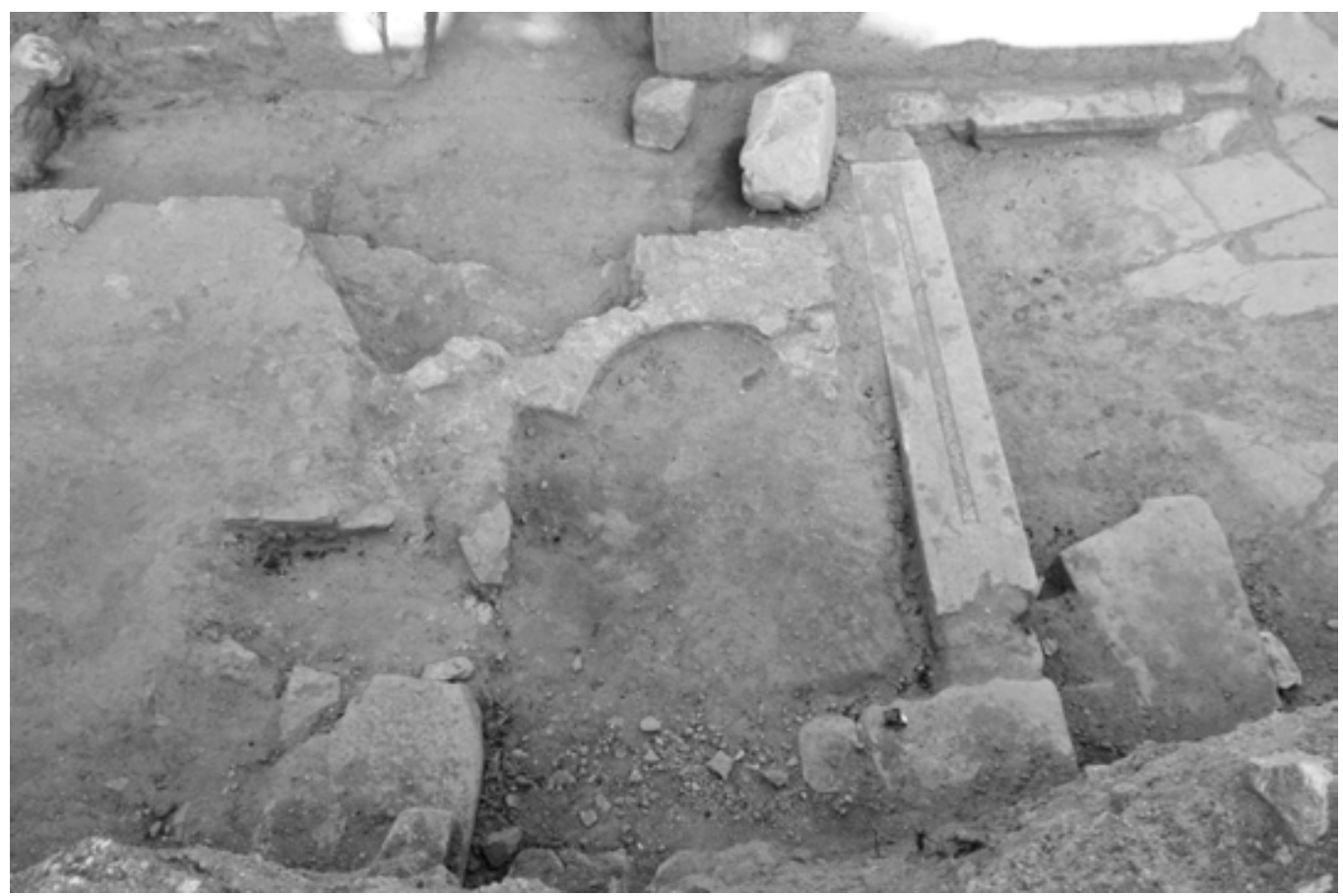

Fig. 2. View of apses in church I Nicaea (Melda Ermiş, İznik ve çevresi Bizans devri mimari faaliyetinin değerlendirilmesi- Evaluation of architectural activities in an around Iznik during Byzantine era, Ph. D. Dissertation. Istanbul University, 2009, ill. 114, p. 189)

\section{Church 1 Iznik}

Ruins of a small church were discovered during minor restorations held in 2008. Until 2012, when a major restoration commenced, it was visible in the city part of Lefke gate. Two apses of the church were located immediately next to the northern archway of the gate. Since the aim of the works was to reach the Roman period road level, newly discovered church was not excavated. The remains of the church structure measured approximately $6 \times 2.4$ metres (Fig. 2). Both apses face east. Neither construction technique nor material were available for study. Due to this, dating of the structure is difficult. The possible dates of the church are either post 1064 earthquake, when major restoration of the city walls was done, or the beginning of the $13^{\text {th }}$ century when the exiled Byzantine court settled in the city. Having churches or chapels by the city gates or walls for spiritual protection is a common phenomenon. One of the most recent examples was found in Apolyont walls [4, pp. 163-168].

\section{Church 2 Iznik}

During restorations of the gates of the city walls by the gate of Istanbul aiming to reach the original Roman road level simple graves were unearthed. All the graves were made of roof tiles (Fig. 3). Soon afterwards a lateral apse and the main apse were discovered. In front of the main apse there was a cavity on the ground made between two rectangular slabs in the form of a circle. This is a clear indication of an altar table support (Fig. 4). The church structure is 


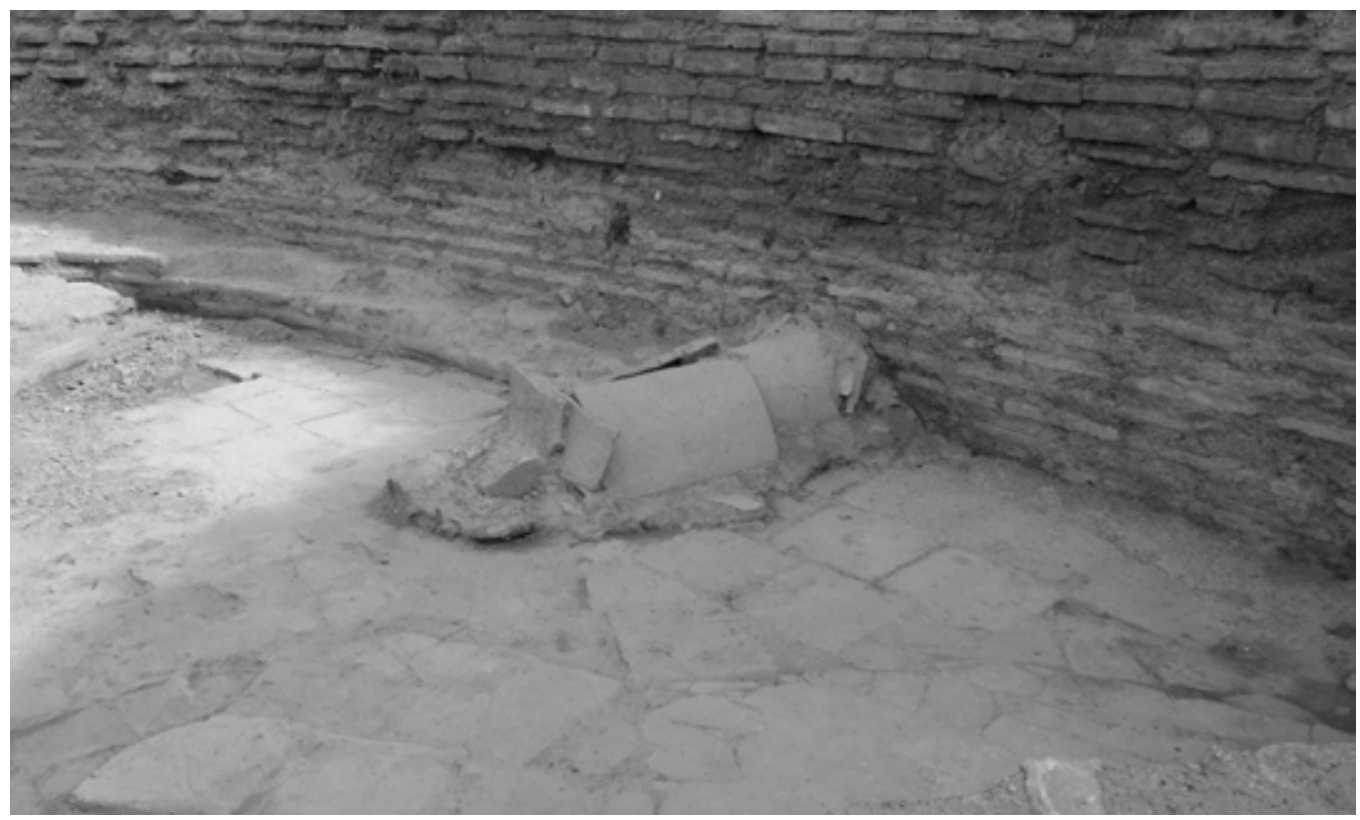

Fig. 3. A roof tile grave in church II Nicaea. Photo by H. Çetinkaya

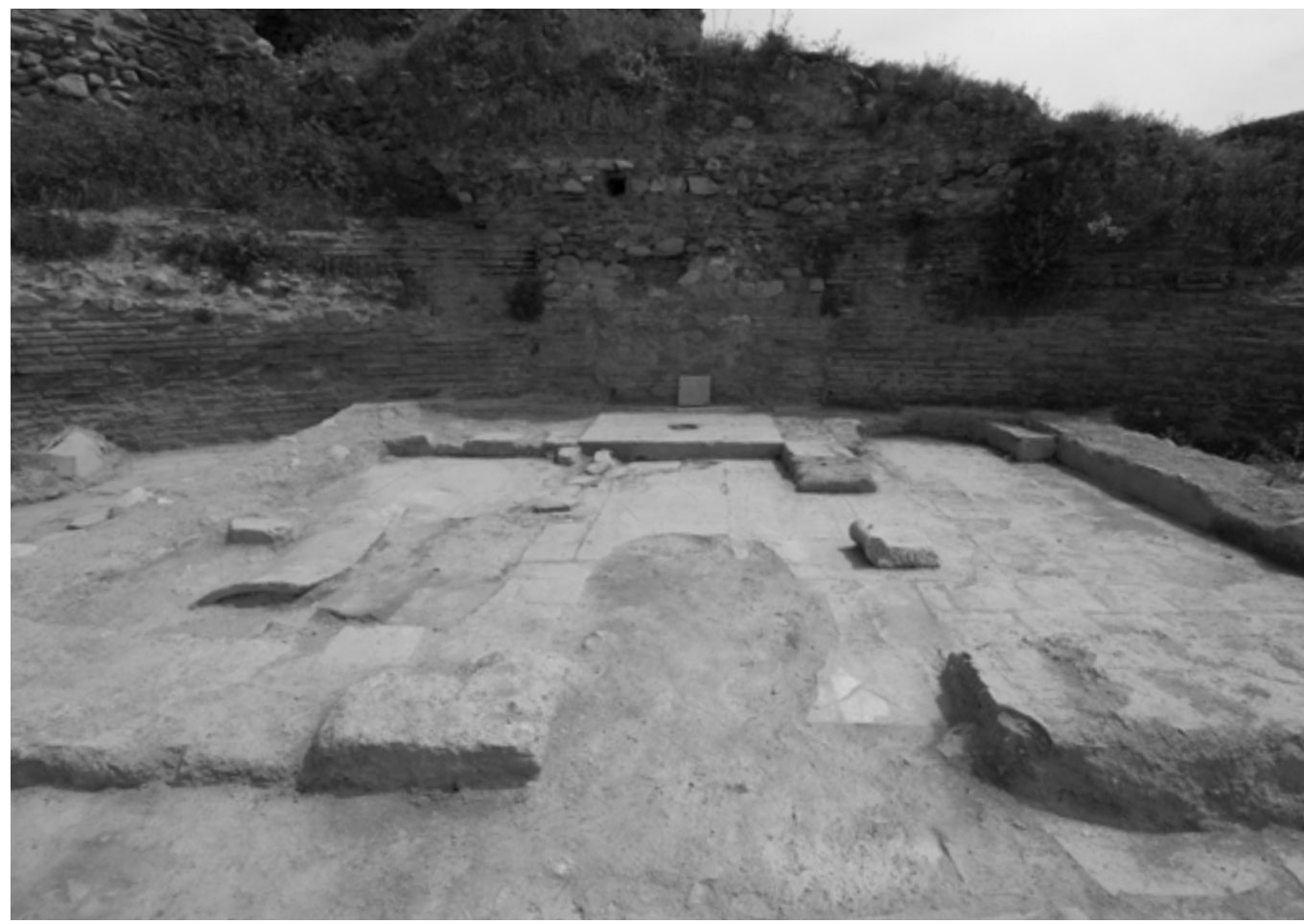

Fig. 4. General view of church II Nicaea. Photo by H. Çetinkaya 
located in the oval area between the outer and inner gates towards East. Ruins of the structure are at most 0.3 metres which does not allow any further studies of both material and construction technique. Since the church is not fully excavated, its exact measurements are not known, but hypothetically they may be approximately $6 \times 10$ metres.

The dating of the church is not clear but it is safe to assume that it was built during the large scale construction campaign of the Laskarids at the beginning of the $13^{\text {th }}$ century A.C.E. During the restorations of the city walls they were praised and considered to be "the greatest ornament of Nicaea" [7, p. 155]. Since they were given such importance, spiritiual protection, namely building churches attached to them, must have played a major role. That is why new churches were built adjacent to the gates.

Dedication of the church is problematic but according to a $17^{\text {th }}$ century traveler there was a church of Saint Nicholas on Istanbul gate [8, pp. 276-278]. It is interesting to note that until the beginning of the $20^{\text {th }}$ century A.C.E. frescoes of this chuch were visible [5, p. 98].

By this, whether it was meant to be on one of the towers or the newly discovered church is not clear, but it has to be taken into consideration.

\section{Church 3 Iznik}

In 2012 it was decided to enlarge the museum of Iznik. Empty space at the west of the museum was chosen for the annex building. During the excavation process the Byzantine period pipelines, wells, alleys and shops were discovered (Fig. 5). At the northernmost part of the lot 27 graves made of roof tiles were discovered. Part of the floor towards East was covered with opus sectile (Fig. 6). It is the same style as the bema of Iznik Hagia Sophia, which was dated to the $5^{\text {th }}-6^{\text {th }}$ centuries [14, p. 47]. At the western end there are four spolia pedestals which most probably supported a baldacchino (Fig. 7). If it was the case, this could have been the site for the relics. Since the site of the church is not fully excavated, it is difficult to suggest its original shape and size. In the East the beginning of the apse can be noted.

Existing walls of the church were made of stone and bricks. The thickness and the shape of the bricks indicate an early date which corresponds with the opus sectile floor. Dedication of the church is problematic since no inscriptions were found. A nunnery called Nikaias was already in existence by the reign of Justinian I who had it restored [11, p. 118]. Basing on the bricks, the walls construction technique, and the opus sectile floor, the ruins of the structure could be dated to the $5^{\text {th }}$ century A.C.E. On spot observations of the field anthropologists indicate 13 female skeletons found in and around the church. To conclude, identification of the ruined church as the monastery of Nikaias probably from the $5^{\text {th }}$ century A.C.E. could not be entirely wrong, given the above mentioned evidence.

\section{Church 4 Bursa}

The region of the city of Prusias was given by the Macedonian king Philippos V to Prusias I, his brother-in-law, in 202 B.C.E. The city was named after the founder as Prusias and must have been founded between 202 B.C.E. and 182 B.C.E. when he died [17, p. 490]. Under Roman rule Prusias, together with other eleven Bithynian cities, was permitted to be autocephalus $[19, \mathrm{p} .491]$. In the $6^{\text {th }}$ century it became a military command center and was visited regularly by the emperors because of its hot springs [6, p. 1750]. 

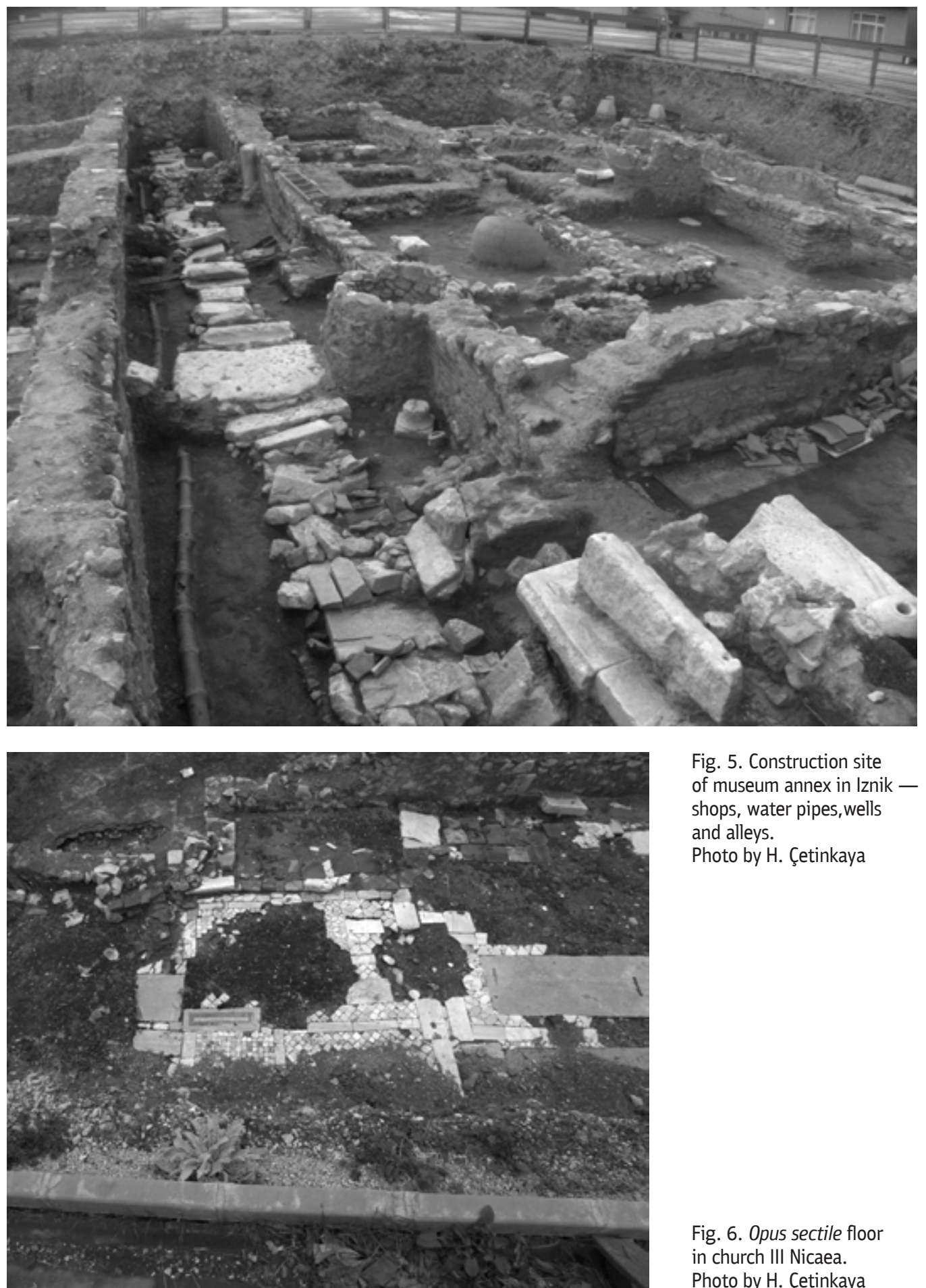

Fig. 5. Construction site of museum annex in Iznik shops, water pipes, wells and alleys.

Photo by H. Çetinkaya

Fig. 6. Opus sectile floor in church III Nicaea.

Photo by H. Çetinkaya 


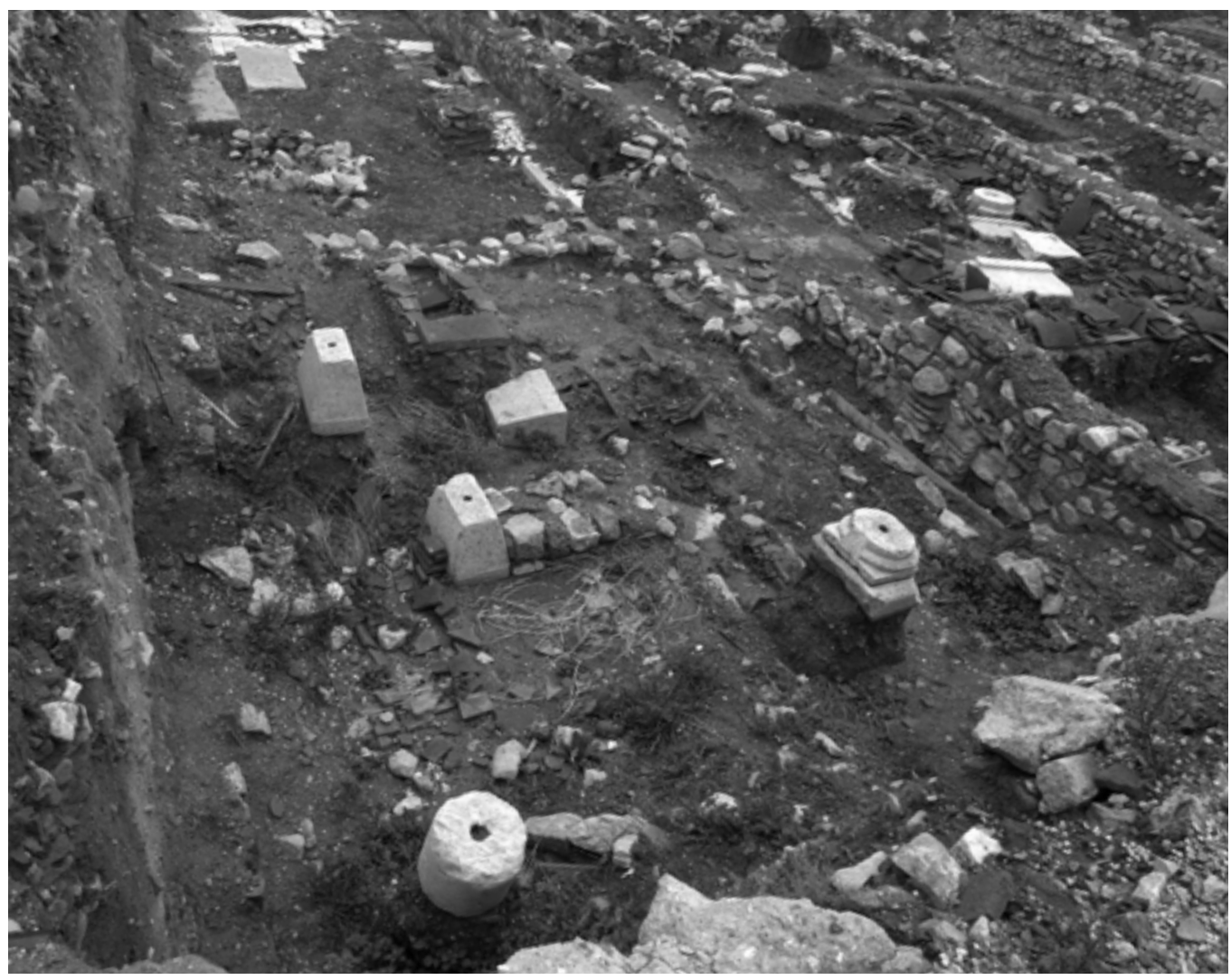

Fig. 7. Pedastals supporting a baldachino in church III Nicaea. Photo by H. Çetinkaya

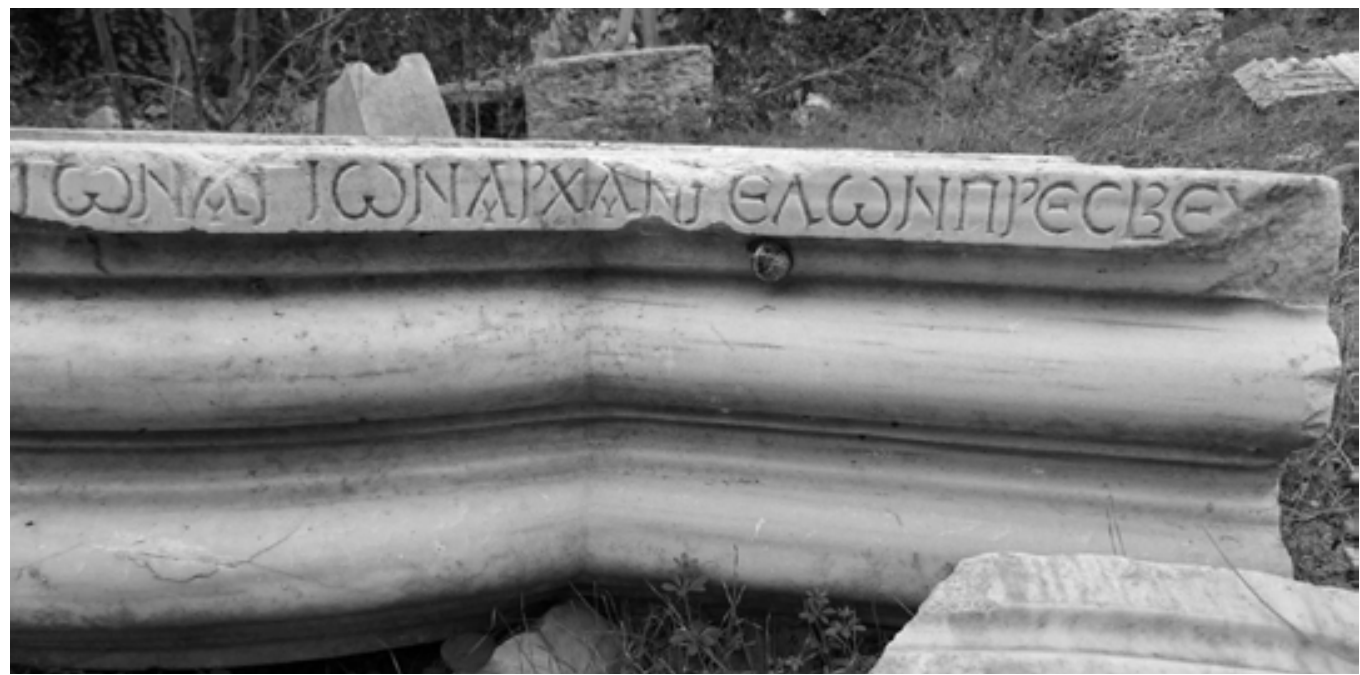

Fig. 8. Inscription carved on the ambo of Church IV Prusa ad Olympum. Photo by H. Çetinkaya 
Monasticism started here by the foundation of the first institution in the $5^{\text {th }}$ century. Between the $8^{\text {th }}-10^{\text {th }}$ centuries monasticisim flourished in the area reaching around 50 monasteries including one nunnery [12, pp. 131-136].

Mount Olympus had played an important role in the development of monasticism. On the slopes of mount Olympus the city must have had congregational churches. It is nearly a general consensus that there were only three or four churches in Prusa ad Olympum. These were Hexapterygos, Prodromos, Kabalos and an anonymous large monastery [11, p. 175].

During the restoration of the city walls of Prusa ad Olympum in 2012 a church with three semicircular apses was discovered. Next to them were the marble supports of the templon followed by the pieces of side slabs of an ambo and its bottom part. The latter offered very important information, namely, an inscription which helps to identify the church (Fig. 8). Inscription is on the both sides of the bottom part of the ambo, parts of it are broken. Inscrip-

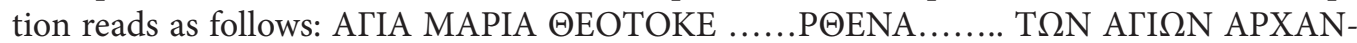

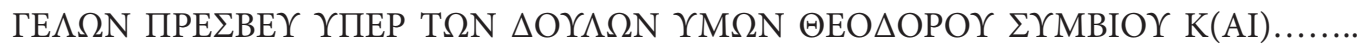
ION T $\Omega N$ KTI $\Sigma A N T \Omega N$ TON OIKON TOYTON (Holy Mary Mother of God .......... of the Holy Archangels pray for us your servants Theodoros (and) ............ (possibly name of his wife) for having founded this house of worship).

Such ambos are known from the Early Christian period. Some of the best examples are in Istanbul Archaeological museum, which are from Thessaloniki and in the garden of Hagia Sophia, which is from Beyazit churches. All examples are from the $5^{\text {th }}-6^{\text {th }}$ centuries. Judging from the quality of the material, Proconnesan marble, and its location overlooking the plain by the city walls, this church must have been one of the most prominent Early Byzantine buildings of the city.

In fact, within approximately 100 metres there was another Byzantine church later to be used as the tomb of Ottoman sultan Orhan (Ill. 38). It was thought to be the church of the monastery of John the Theologian. It is also interesting to note that there was a synthronon in this church typical of Early Byzantine period [8, pp. 146-148].

Dedication of the newly discovered church is not clear. But having the names of Holy Mary and the Archangels might be taken as a reference and most probably the church was dedicated to them.

To conclude, although historical sources, travelers' accounts and secondary sources are important, without tangible material available they remain as theoretical sources. Discoveries such as the ones mentioned above, with the help of sources, contribute to understanding the topography of the cities.

\section{References}

1. Appianus of Alexandria. The Roman History of Appian of Alexandria, vol. 1. Transl. by H. White. London, MacMillan and Co. Ltd. Publ., 1899. 528 p.

2. Bekker-Nielsen T. Urban Life and Local Politics in Roman Bithynia The Small World of Dion Chyrsostomos. Aarhus, Aarchus University Press Publ., 2008. 211 p.

3. Cohen G. M. The Marriage of Lysimachus and Nicaea. Historia: Zeitschrift für Alte Geschichte, 1973, vol. 22, no. 2, pp. 354-356.

4. Çetinkaya H. A Byzantine Chapel at Apolyont/Gölyazı. Anatolia Antiqua, 2010, vol. 18, pp. 163-168. 
5. Foss C.; Winfield D. Byzantine Fortifications. Pretoria, University of South Africa Publ., 1986, 1986. $298 \mathrm{p}$.

6. Foss C. Prousa. Talbot A. M. (ed.). The Dictionary of Byzantium, vol. 3. New York; Oxford, Oxford University Press Publ., 1991, p. 1750.

7. Foss C. Nicaea: A Byzantine Capital and Its Praises. Brookline, Hellenic College Press Publ., 1996. 256 p.

8. Grélois J.-P. (ed.). Dr. John Covel, Voyages en Turquie, 1675-1677. Paris, P. Lethielleux Publ., 1998. 438 p. (in French).

9. Herodotus. Histories. Godley A. D. (transl.). London, W. Heinemann Publ., 1938. 569 p.

10. Janin R. La Bithynie sous l'empire byzantin. Echos de Orient, 1921, vol. 20, pp. 178-319 (in French).

11. Janin R. Les églises et les monasteres des grands centres Byzantins. Paris, Peeters Publ., 1975. 493 p. (in French).

12. Menthon B. Une terre de legende. L'Olympe de Bithynie. Paris, Bonne-Presse Publ., 1935. 256 p. (in French).

13. Merkelbach R. Nikaia in der römischen Kaiserzeit. Düsseldorf, Rheinisch-Westfälische Akademie der Wissenschaften Vorträge Publ., 1987. 41 p. (in German).

14. Möllers S. Die Hagia Sophia von Iznik/Nikaia. Alfter, Verlag und Datenbank für Geisteswissenschaften Publ., 1994. 80 p. (in German).

15. Schneider A. M.; Karnapp W. Die Stadtmauer von Iznik (Nicaea). Berlin, Archaeologisches Institut des Deutschen Reiches Publ., 1938. 55 p. (in German).

16. Schneider A. M. The City Walls of Nicaea. Antiquity, 1938, vol. 12, no. 48, pp. 437-443.

17. Strobel K. Prusa, Prusa ad Olympum. Cancik H.; Schneider H. (eds.). Der Neue Pauly: Enzyklopädie der Antike, vol. 10. Stuttgart; Weimar, J. B. Metzler Publ., 2001, p. 490 (in German).

18. Şahin S. Katalog der antiken İnschriften des Museums von Iznik (Nikaia), part 1. Bonn, Rudolf Habelt Verlag Publ., 1979. 328 p. (in German).

Title. Four Newly Discovered Churches in Bithynia.

Author. Halûk Çetinkaya - Ph. D., associate professor. Istanbul Mimar Sinan Fine Arts University. Silahşör cad. No: 85 Bomonti-Şişli, İstanbul, Turkey. haluk.cetinkaya@msgsu.edu.tr

Abstract. During restorations held in Nicaea/İznik and Prusa ad Olympum/Bursa four new churches were discovered. Since restoration work did not aim at excavating the accidentally discovered churches this article intends to shed light by making use of the material available. Three of the churches were from Nicaea, two of which by the main gates of the city walls and the third one in the area next to the museum building of İznik. The church discovered in Bursa is located next to the city walls. Despite its unfinished excavation it has revealed immense material including the ambo with an inscription. The aim of this article is to contribute to the database of Byzantine monuments.

Keywords: Bithynia; monasticism; Nicaea; Prusa ad Olympum.

Название статьи. Четыре недавно открытые церкви в Вифинии.

Сведения об авторе. Четинкая Халюк - Ph. D., доцент. Университет изящных искусств имени Мимара Синана, Силахшёр, 85, Стамбул, Турция. haluk.cetinkaya@msgsu.edu.tr

Аннотация. В ходе реставрационных работ в Никее (Изнике) и Прусе (Бурсе) были выявлены четыре новые церкви, относящиеся к разным периодам от V до XIII в. Поскольку полные раскопки случайно найденных церквей не входили в число задач этих работ, автор статьи ограничивается имеющимся материалом. Три церкви были обнаружены в Никее, две из них - у главных ворот в городской стене, а третья на участке, примыкающем к зданию Археологического музея. Церковь, открытая в Бурсе, находится рядом с городскими стенами. Несмотря на то что её раскопки не завершены, здесь было обнаружено много материала, в том числе амвон с надписью. Цель этой статьи - пополнить свод византийских памятников.

Ключевые слова: Вифиния; монашество; Никея; Пруса у Олимпа. 


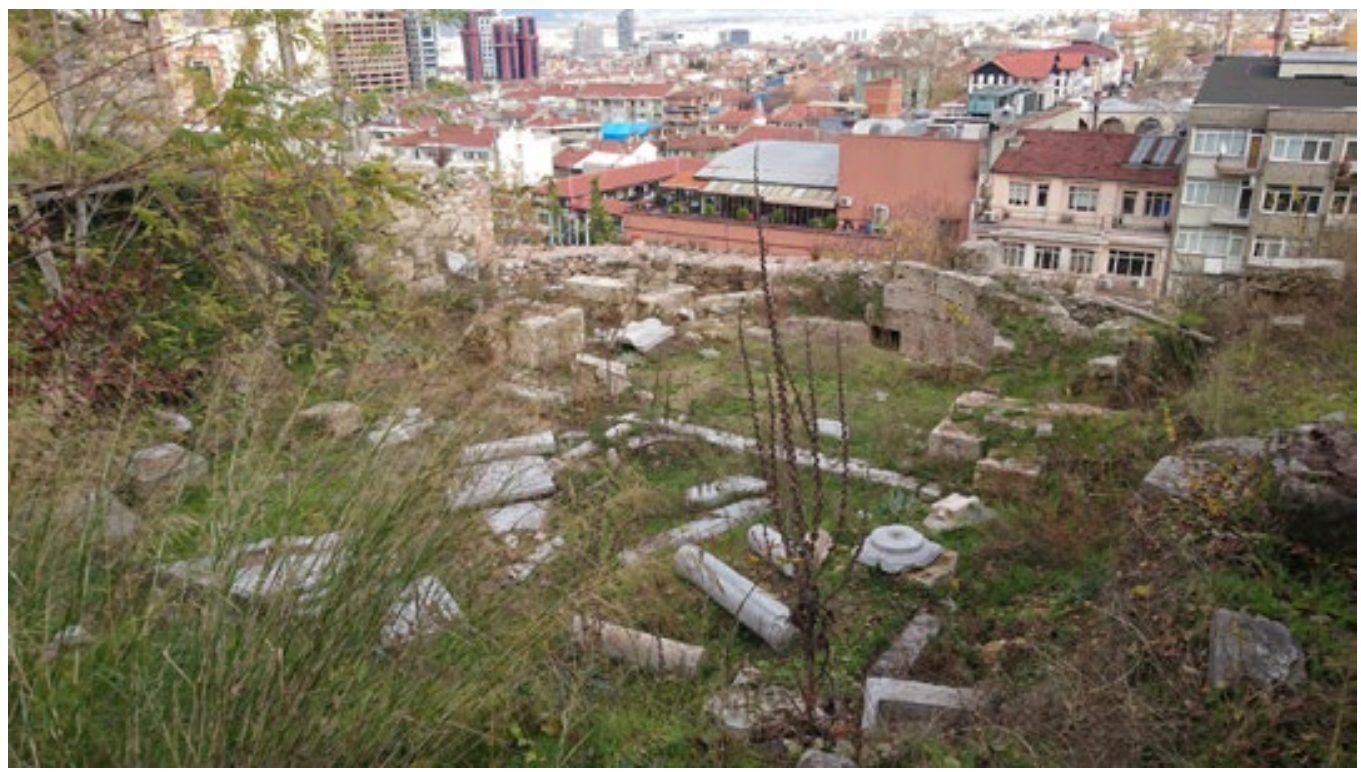

III. 37. General view of church ruins discovered in Prusa ad Olympum. Photo by H. Çetinkaya

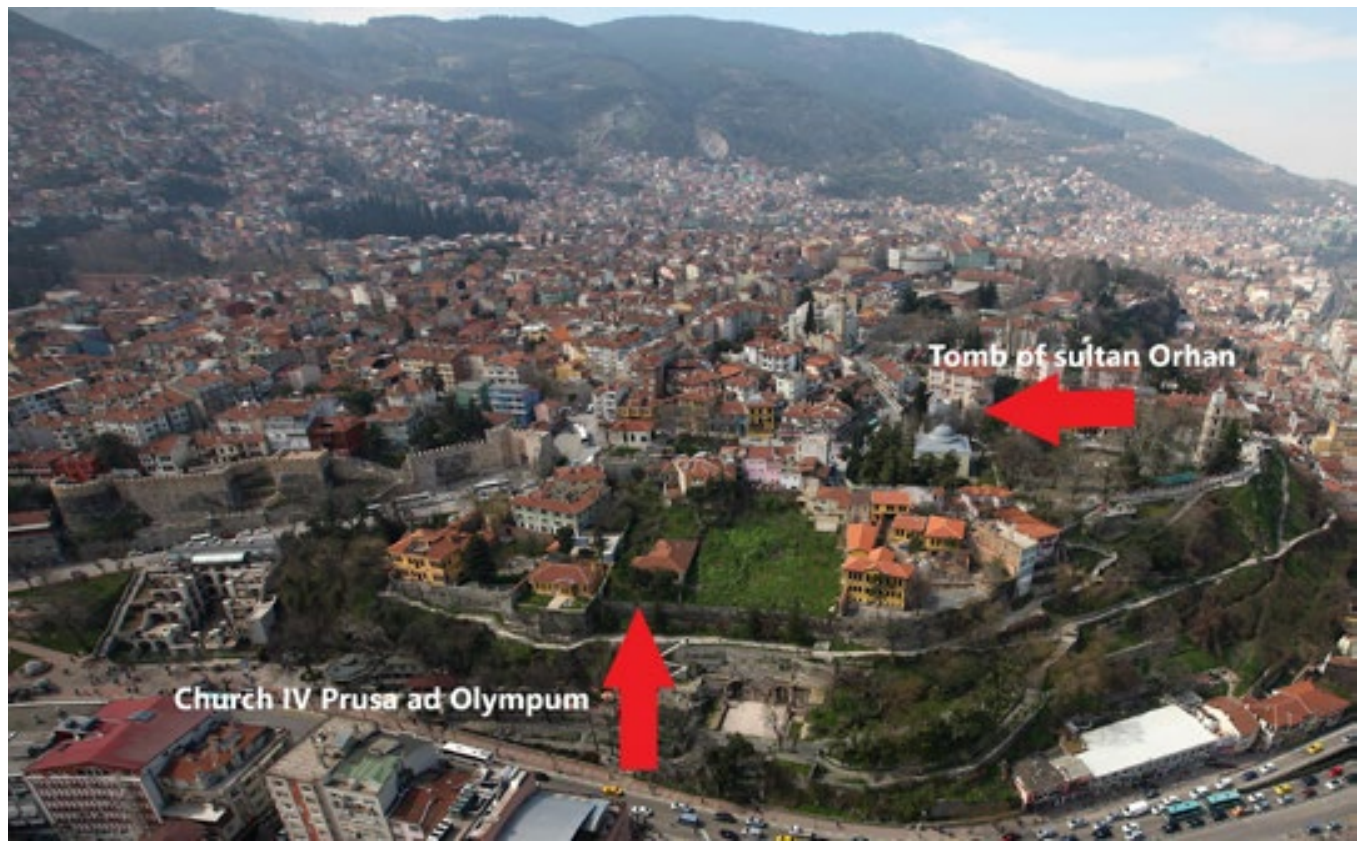

III. 38. Aerial view of church IV and mausoleum of Ottoman sultan Orhan which was formerly a Byzantine church. Bursa Greater City Municipal archive www. http://fotograf.bursa.com.tr/tophane-tarihi-evler/ 